\title{
THE SPATIAL VARIABILITY OF MACROALGAL COMMUNITIES AND THEIR FUNCTIONAL GROUPINGS ON THE FRINGING REEFS OF GHARDAQAH, EGYPT
}

\author{
Islam M. El-Manawy \\ Botany Dept, Fac. of Science, Suez Canal Univ., Ismailia, Egypt
}

\begin{abstract}
Spatial variation in cover and biomass of macroalgae was investigated during February 3-5, 2008 on three locations representing the north, mid and south reefs of Ghardaqah. Data were collected from inner, middle, outer and fore zones using $1 \mathrm{~m}^{2}$ quadrate. Four functional groups were distinguished: upright leathery, upright fleshy, turf and crustose coralline algae. Cover and biomass were higher at both middle and outer reefs than inner and fore reefs. Species composition and abundance and the relative contribution of each group to the overall cover and biomass considerably varied in relation to the reef health. Abundant and conspicuous upright leathery assemblage of Cystoseira with Sargassum, Turbinaria and Hormophysa dominated the northern reefs and benefited from increases in substrate availability due to large areas of dead corals. Living corals did not exceed 5\% of this reef and dominated by crustose corallines. Mid region had low macroalgal coverage of upright, crustose and turf algae (all not exceed $30 \%$ ), and could be an example of the healthy reef. Southern reef had low abundance of leathery, crustose and turf assemblages, but had high upright fleshy algae and could be considered as an intermediate stage of reef degradation. As a group, fleshy upright macroalgae such as Caulerpa, Halimeda, Amphiroa, Gelidium, Padina and Dictyota are likely to benefit from many of the environmental changes brought about by tourism. Enteromorpha intestinalis was rare (cover $3 \% \pm 0-2$ ) on reef flat, but extensively colonized the bottom and sides of yachts, their mooring ropes and drifted in very large amount on the beaches.
\end{abstract}

Keywords: Coral reef, Egypt, Functional groupings, Ghardaqah, Macroalgae.

\section{Introduction}

Benthic algae on coral reefs can be considered as three main categories (algal turfs, upright macroalgae, and crustose calcareous algae) with several functional groups, reflecting both physiological traits and ecological roles of algae (Littler et al, 1983; Steneck and Dethier, 1994). Upright macroalgae are subdivided into calcareous articulated algae and fleshy algae that further subdivided into foliose, terete corticated, leathery algae. Algal turfs contribute by a large proportion to primary production on a coral reef but have low standing crop, indicating high turnover rates (Klumpp and McKinnon 1992; Gattuso et al, 1998). The part contributed by upright fleshy and calcareous algae is also important (Schaffelke and Klumpp, 1997; Chisholm, 2003). Crustose calcareous 
algae are significant framework builders and cementers on coral reefs (Littler and Littler, 1984; Chisholm, 2000) and are suggested to induce settlement of coral larvae in the reefs (Harrington et al, 2004). Leathery and foliose forms constitute grazing refuges (McCook 1996). Upright calcareous algae, such as Halimeda and Amphiroa, make important contributions to the production of marine sediments (Marshall and Davies, 1988).

Benthic algal colonization and abundance have also been recognized as more important consequences of coral reef degradation. Natural and anthropogenic disturbances often lead to coral mortality and the dead coral skeletons are then rapidly colonized by diverse algal communities (Diaz-Pulido and McCook, 2002; Halford et al, 2004). Benthic algae may also accelerate reef degradation. A reef community dominated by abundant, high-biomass algal turfs or larger, fleshy macroalgae may lead to overgrowth, smothering and/or shading of corals, the exclusion of coral recruitment, and increases in pathogens, resulting in an alternate stable state, with decreased ecological, economic and aesthetic value (Hughes, 1994; Nugues et al, 2004; Smith et al, 2006). Reductions in herbivory due to overfishing and increases in nutrient inputs have been shown to cause increases in fleshy macroalgal abundance, leading to coral overgrowth by algae and, ultimately, reef degradation (Steneck and Dethier, 1994; McCook, 1999; Szmant, 2002).

Numerous publications have been dealt with the benthic algal taxonomy, distribution and habitats in the northern Red Sea (e.g. Nasr, 1947; Papenfuss, 1968; Hegazy; 1992; Abou-Aisha et al., 1995; 2000Rasser and Piller, 1997; ElManawy and Gab-Alla, 2000; El-Manawy and Shafik,) and also in the southern Red Sea (e.g. Walker 1987; Sheppard 2000; Lipkin and Silva 2002; Ateweberhan et al, 2006). With increasing urbanization, many reefs are experiencing increasing levels of stress from anthropogenic sources including over-fishing, pollution, eutrophication, coastal development, ship grounding and over exploitation by tourists (Hanafi, pers. comm.). It is therefore essential to assess the implications of such disturbances to the benthic biota to facilitate the implementation of management strategies. Ghardaqah is a city, stretching for about $40 \mathrm{~km}$ along the seashore of the Red Sea, and it does not reach far into the surrounding desert. The city was founded in the early 20th century as a small fishing village, and since two decades has been continually enlarged to become an international center for aquatic sports. The coral ecosystems inshore and offshore are considered some of the finest in the world. Information about the changes in macroalgal communities in relation to the recent extensive exploitation of the reef ecosystems is lacking.

In the present work, two specific questions have been addressed; what is the contribution of each functional group to the total benthic algal cover and biomass in different reef zones? Do different functional groups show different responses to the import of tourism? The main reason for this study was to

Egyptian J. of Phycol. Vol. 9, $2008 \quad$ - 56 - 
evaluate the reef health conditions, in order to facilitate the implementation of appropriate management strategies that may protect the reefs and potentially allow their recovery.

\section{Materials and Methods}

The study was conducted during February 3-6, 2008 on three sites at Ghardaqa (Fig. 1). Site I represents the northern reef of Ghardaqa, a sheltered site on the mainland, located near the Marine Biological Institute $\left(27^{\circ} 19^{\prime} 48^{\prime \prime} \mathrm{N}, 33^{\circ}\right.$ $44^{\prime}$ E). Site II represents a middle reef, which is relatively offshore and exposed to wave action $\left(27^{\circ} 17^{\prime} 24^{\prime \prime} \mathrm{N}, 33^{\circ} 48^{\prime} \mathrm{E}\right)$. Site III represents a southern reef $\left(27^{\circ} 09^{\prime}\right.$ $\mathrm{N}, 33^{\circ} 52^{\prime} \mathrm{E}$ ), where there is much affect in this part of the reef from fresh and wastewater runoff from tourist residences nearer to the shore (Hanafi, pers. comm.).

Species/functional groups of macroalgae were monitored using $1 \mathrm{~m}^{2}$ quadrate sampling. At each site, the reef flat was divided into three zones (inner, middle and outer) in addition to the fore reef. The division of reef flat was based on the physiognomy of algal vegetation. At all locations, large macroalgae were absent from the fore reef. At site I, the living corals did not exceed 5\% of the area of this site and concentrated only on the fore reefs. Cystoseira myrica dominated the reef flat with population density that differed according to reef zone. The population was denser and taller in the middle zone. The inner population was less dense and intermixed with some foliose brown algae. On the outer reef flat, Cystoseira density became less and intermixed with Hormophysa, Turbinaria and Sargassum. Site II characterized by more living corals, inter-coral channels and scars and widespread macroalgae. At site III, turf forming algae, like filamentous and juvenile forms, dominated the inner reef flat; fleshy algae, like Codium and Caulerpa, dominated the outer reef flat, while both species co-occurred on the middle reef flat. Dead coral skeletons and coral rubble substrates were potentially suitable for macroalgal growth.

Three randomly scattered quadrates were sampled in each reef zones (inner, middle, outer and fore). For accurate estimation, each quadrate was subdivided into $100,10 \times 10 \mathrm{~cm}$ sub-quadrates. Reef algae were categorized into four functional groups based on their growth form and ecological characteristics (Steneck and Dethier 1994). The following groups were distinguished: upright leathery canopy, upright fleshy canopy (including foliose, terete corticated and calcareous articulated algae), turf algae (filamentous and small corticated forms) and crustose coralline algae. Percent cover and biomass was used to quantify the abundance of macroalgae. Cover in a quadrate was measured in the field for each species of each functional group, and the average of the three quadrates was calculated. The biomass was determined by harvesting all plants present in the quadrates, sorted by species, and their dry matters were determined. 


\section{Results}

Macroalgae on Ghardaqa reefs (Fig. 1) occupied a wide variety of habitats, including shallow and deep coral reefs, sandy inter-reef areas and dead intertidal zones. A total of 32 species were found (Table 1) and distinguished into four functional groups: upright leathery canopy (ULC), upright fleshy canopy (UFC), turf algae (TA) and crustose corallines (CC). A few scattered plants of other species were present here and there, but of less ecological importance and thus excluded from the present analysis.

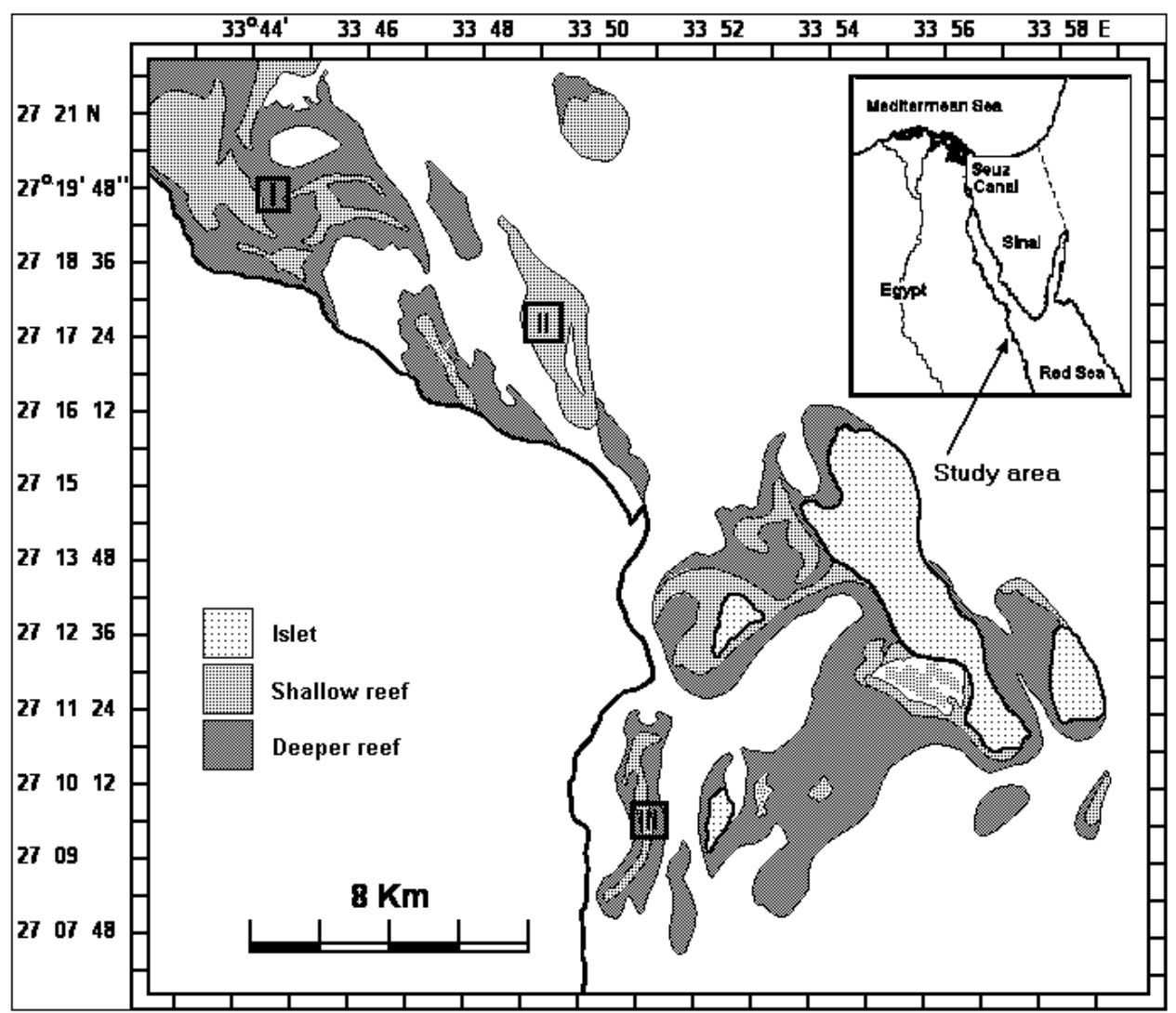

Figure 1: Location of Ghardaqa on the Red Sea, and the sampling locations.

\section{Upright leathery canopy}

Upright leathery canopy composed of five brown species all of order Fucales (ULC; Table 1). There was a marked variation in the spatial distribution of these species within reef habitats (Fig. 2). The middle and outer zones were generally characterized by more leathery canopy than inner zone, but none of canopy species were found on fore reefs. High macroalgal abundance was 
recorded from the reef flat of site I, especially on the middle reef (up to ca. 500 $\mathrm{gm} \mathrm{m}^{-2}$ at ca. $65 \%$ cover).

Table 1: Cover percent of each species at each site. Values are expressed as average with standard deviation $(M \pm S D)$.

\begin{tabular}{|c|c|c|c|c|c|c|c|}
\hline \multirow{2}{*}{\multicolumn{2}{|c|}{ Species $\backslash$ Sites }} & \multicolumn{2}{|c|}{ Site I } & \multicolumn{2}{|c|}{ Site II } & \multicolumn{2}{|c|}{ Site III } \\
\hline & & $\mathbf{M}$ & SD & $\mathbf{M}$ & SD & $\mathbf{M}$ & SD \\
\hline ULC & Cystoseira trinodis (Forsskal) C Agardh & 18 & 14 & 1 & $\mathbf{0}$ & 2 & 1 \\
\hline ULC & Hormophysa triquetra (C Agardh) Kützing & 4 & 1 & 1 & $\mathbf{0}$ & 6 & 1 \\
\hline ULC & Sargassum latifolium (Turner) C Agardh & 7 & 2 & & & 2 & 1 \\
\hline ULC & Sargassum subrepandum (Forsskal) C Agardh & 13 & 8 & & & 3 & 1 \\
\hline ULC & Turbinaria triquetra (J Agardh) J Agardh & 3 & 1 & 1 & $\mathbf{0}$ & 5 & 1 \\
\hline UFC & Halimeda opuntia (Linnaeus) Lamouroux & 1 & $\mathbf{0}$ & 2 & 1 & 2 & $\mathbf{0}$ \\
\hline UFC & Halimeda tuna (Ellis \& Solander) Lamouroux & & & 1 & $\mathbf{0}$ & 2 & 1 \\
\hline UFC & Caulerpa racemosa (Forsskål) J. Agardh & 2 & $\mathbf{0}$ & 2 & $\mathbf{0}$ & 3 & 1 \\
\hline UFC & Codium tomentosum Kützing & & & & & 1 & $\mathbf{0}$ \\
\hline UFC & Colpomenia sinuosa Derbes \& Solier & 1 & $\mathbf{0}$ & 1 & $\mathbf{0}$ & 4 & 4 \\
\hline UFC & Dictyosphaeria cavernosa (Forsskal) Borgesen & 1 & $\mathbf{0}$ & 1 & $\mathbf{0}$ & 3 & 1 \\
\hline UFC & Dictyota dichotoma (Hudson) Lamouroux & 2 & 1 & 2 & $\mathbf{0}$ & 3 & $\mathbf{0}$ \\
\hline UFC & Hydroclathrus clathratus (C Agardh) Howe & 1 & $\mathbf{0}$ & & & 2 & 1 \\
\hline UFC & Padina pavonica (Linnaeus) Thivy & 3 & 1 & 2 & $\mathbf{0}$ & 7 & 2 \\
\hline UFC & Pocockiella variegata (Lamouroux) Papenfuss & 1 & $\mathbf{0}$ & 2 & $\mathbf{0}$ & 2 & $\mathbf{0}$ \\
\hline UFC & Amphiroa fragillissima (Linnaeus) Lamouroux & 3 & $\mathbf{0}$ & 3 & 2 & 5 & 1 \\
\hline UFC & Digenea simplex (Wulfen) C Agardh & 1 & $\mathbf{0}$ & 1 & $\mathbf{0}$ & 2 & 1 \\
\hline UFC & $\begin{array}{l}\text { Galaxaura cylindrica (Ellis \& Solander) } \\
\text { Lamouroux }\end{array}$ & & & & & 3 & 1 \\
\hline UFC & Gelidiella acerosa (Forsskal) Feldmann \& Hamel & & & 2 & $\mathbf{0}$ & 2 & $\mathbf{0}$ \\
\hline UFC & Gracilaria disticha (J Agardh) J Agardh & & & & & 2 & $\mathbf{0}$ \\
\hline UFC & Hypnea cornuta (Kützing) J Agardh & 1 & $\mathbf{0}$ & & & 2 & 1 \\
\hline UFC & Jania adhaerens Lamouroux & & & & & 1 & 1 \\
\hline UFC & Liagora farinosa Lamouroux & & & 2 & $\mathbf{0}$ & 2 & 1 \\
\hline TA & Enteromorpha intestinalis (Linnaeus) Greville & 3 & $\mathbf{0}$ & & & 3 & 2 \\
\hline TA & Giffordia mitchellae (Harvey) Hamel & 2 & 1 & 2 & 1 & 1 & $\mathbf{0}$ \\
\hline TA & Gelidium pusillum (Stackhouse) LeJolis & 3 & 1 & 3 & 1 & 3 & $\mathbf{0}$ \\
\hline TA & Polysiphonia gorgoniae Harvey & & & & & 1 & $\mathbf{0}$ \\
\hline TA & Spyridia filamentosa (Wulfen) Harvey & 2 & $\mathbf{0}$ & 2 & 1 & 1 & $\mathbf{0}$ \\
\hline TA & Juvenile macroalgae & 4 & 1 & 4 & 1 & 4 & 2 \\
\hline $\mathbf{C C}$ & Lithophyllum incrustans Philippi & 2 & 2 & 3 & $\mathbf{0}$ & 2 & 1 \\
\hline $\mathbf{C C}$ & $\begin{array}{l}\text { Neogoniolithon fosliei (Heydrich) Setchell \& } \\
\text { Mason }\end{array}$ & & & 2 & 1 & 1 & 1 \\
\hline $\mathbf{C C}$ & Peyssonelia rubra (Greville) J Agardh & 2 & 1 & 2 & $\mathbf{0}$ & 2 & $\mathbf{0}$ \\
\hline $\mathbf{C C}$ & Porolithon onkodes (Heydrich) Foslie & 1 & $\mathbf{0}$ & 3 & 1 & 2 & 1 \\
\hline
\end{tabular}


At this site, C. myrica, $S$. subrepandum and S. latifolium made up a mixed stand with $18 \% \pm 14,13 \% \pm 8$ and $7 \% \pm 2$ cover, respectively (Table 1). Turbinaria triquetra and Hormophysa triquetra were contributed less to this stand. During the present period of investigation, Sargassum latifolium was represented only by the basal holdfasts and short erect shoots at all site. On other sites, a few individuals of the leathery canopy species were scattered here and there, but made up only small percentages of the algal cover and biomass (Table 1, Fig. 2).
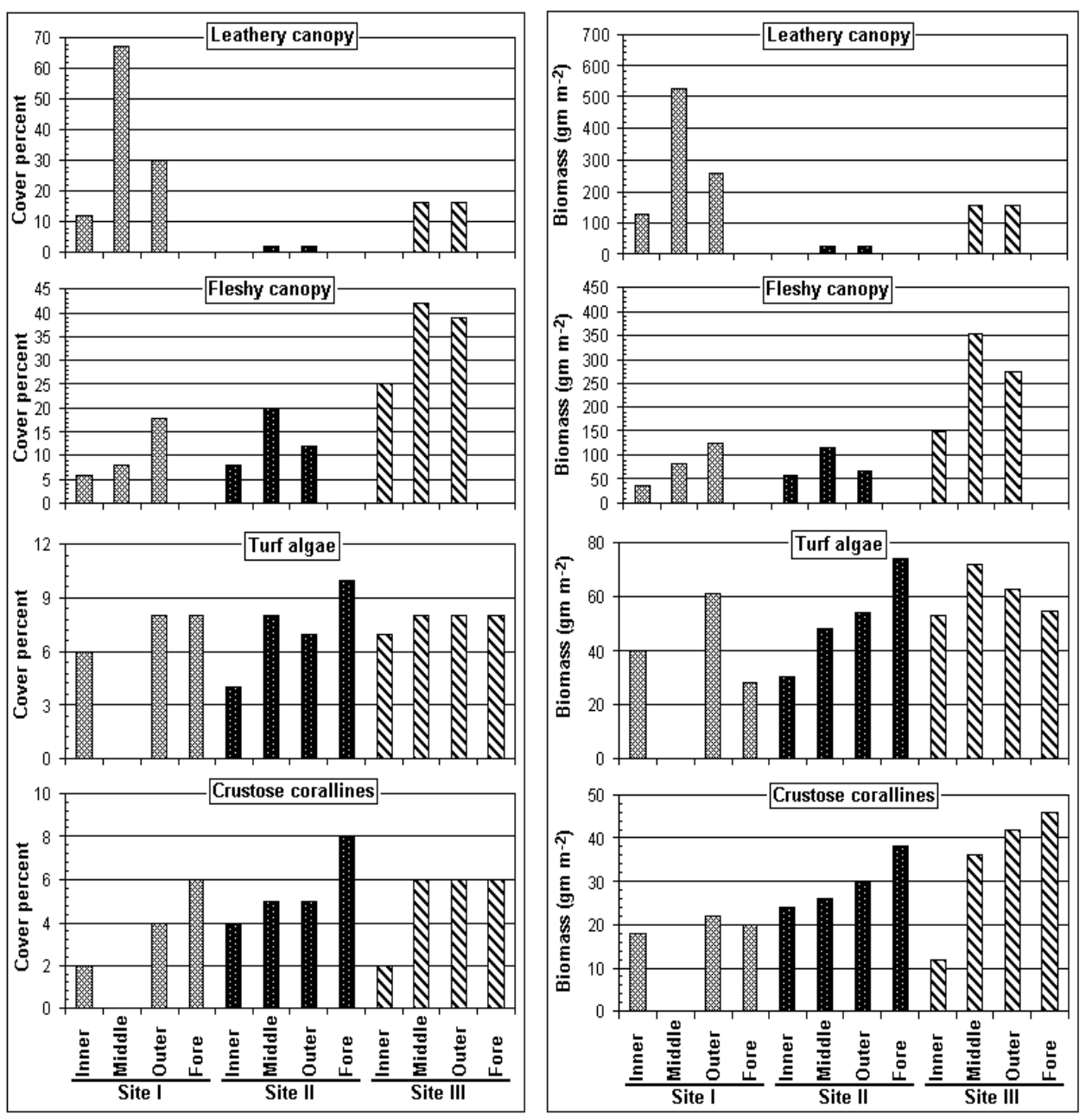

Figure 2: Cover percent (left panel) and biomass (right panel) of the four functional algal groups on each zone of the reef flat (inner, middle, outer and fore) from sites I

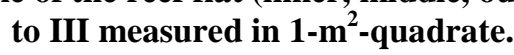




\section{Upright fleshy canopy}

Eighteen species composed the group (UFC; Table 1), four from green algae (Caulerpa racemosa to Dictyosphaeria cavernosa), six from brown algae (Dictyota dichotoma to Pocockiella variegate) and eight from red algae (Amphiroa fragillissima to Liagora farinose). Although this group characterized by a higher diversity of species, it present abundance values (up to ca. $350 \mathrm{gm} \mathrm{m}^{-2}$ at ca. $44 \%$ cover) lower than presented by the upright leathery canopy (Fig. 2). The highest cover and biomass of upright fleshy canopy occurred on the inner, middle and outer reefs of site III, while other two sites had low abundance values. The dense fleshy cover at site III was dominated primarily by Padina pavonica (7\% \pm 2$)$, Amphiroa fragillissima (5\% \pm 1$)$, Colpomenia sinuosa (4\% \pm 4$)$, Caulerpa racemosa $(3 \% \pm 1)$, Dictyosphaeria cavernosa $(3 \% \pm 1)$, Dictyota dichotoma $(3 \%$ $\pm 0)$ and Galaxaura cylindrica $(3 \% \pm 1)$. On fore reefs, the fleshy canopy species were found as juvenile stages, which formed a part of algal turf.

The distribution of fleshy canopy on the reef flat followed a zonation pattern. Close to the beach, large patches of fine sediment hinder the development of any species. Thick mats of Padina pavonica commonly colonized any dead coral substrate that emerged from the sediment. Dictyota dichotoma formed several clumps scattering on the sides of coral heads. Pocockiella variegata was found, with very low biomass, prostrate on reef flats and coral ridges. Amphiroa fragillissima, Halimeda opuntia and Galaxaura cylinderica formed thick clumps in shallow subtidal calm areas, became sparse on reef flat with heavy water motion. The siphonous green Caulerpa have extensive systems of rhizoids that colonized the sandy bottoms in reef channels.

\section{Turf algae}

The turf algae (TA; Table 1) composed of five species; Enteromorpha intestinalis from green algae, Giffordia mitchellae from brown algae and the others were red algae. All reef zones contained turf forming species except at middle reef of the site I, where upright leathery algae were dominant (Fig. 2). Despite the lower number of turf species, their total algal cover did not exceed $10 \%$ (ca. $75 \mathrm{gm} \mathrm{m}^{-2}$ biomass). Giffordia mitchellae and Spyridia filamentosa were found generally on the inner reef, while Gelidium pusillum formed another turf on the fore reef. The green species (Enteromorpha intestinalis) was rare on reef flat (cover $3 \% \pm 0-2$ ), but extensively colonized the bottom and sides of yachts, their mooring ropes and drifted in very large amounts on the beaches. Juvenile stages of other macroalgae were found among these turf algae and contributed by (4\% $\pm 1-2)$ to the cover of this group.

\section{Crustose corallines}

The crustose coralline algae (CC; Table 1) composed of four species, all were of red algae. Their dominance was apparent on outer and fore reef zones (Fig. 2). The highest value was found on fore reef of site II (up to $8 \%$ cover, ca. 
$\left.38 \mathrm{gm} . \mathrm{m}^{-2}\right)$. On fore reef of site III, crustose biomass was more than that found at site II, although the cover was less (Fig. 2). Porolithon onkodes and Lithophyllum incrustans were the major contributors at site III (Table 1), the second species was the principal contributor at site II. P. onkodes formed extensive pinkish to somewhat purplish chalky crusts in intertidal areas exposed to surf action. Due to its tolerance of strong sunlight and desiccation and its crustose nature it is extremely successful in occupying high-wave-energy habitats of fore reef. On dead coral, rubble, and other hard surfaces of the subtidal zone, Peyssonellia rubra was found forming firmly attached red to maroon crusts. Neogoniolithon fosliei was found commonly forming pinkish highly branched nodules on sheltered areas of the reef, but less commonly occurred as a crust.

In general, coralline algal crusts were thicker in shallow water (up to $1 \mathrm{~cm}$ ) and more lightened habitats, getting thinner with the increasing depth. On the intertidal reef flats and in shallow subtidal back reef areas, an association of Lithophyllum incrustans, Porolithon onkodes and Neogoniolithon fosliei were prominent. They either grow directly on corals and/or on each other. Both $L$. incrustans and $N$. fosliei form nearly monospecific rhodoliths and may even form frameworks on the reef flats. In contrast, crustose coralline algae became rare among the upright leathery canopy and only one occurrence of $P$. onkodes was observed.

\section{Contribution of different functional groups to the total macroalgae}

There was a marked variation in the spatial distribution of species within reef habitats (inner, middle, outer and fore zones). Overall macroalgal cover and biomass were higher at both middle and outer reefs than inner and fore reefs (Fig. 3 , upper). The relative proportion contributed by each functional group to this overall cover varied strongly with sites (Fig. 3, mid and lower). On site I, the overall values were $26 \%, 75 \%, 60 \%$ and $14 \%$ on the inner, middle, outer and fore reef, respectively. Upright leathery canopy was the major contributor to these values except on fore zone, where both crustose corallines and turf algae shared to the overall cover.

On site II, the overall cover values were $16 \%, 35 \%, 26 \%$ and $18 \%$ on the inner, middle, outer and fore reef, respectively. The relative contribution of upright leathery canopy was less $8 \%$, while the relative contribution of upright fleshy canopy was up to $57 \%$. This site was colonized by more turf and crustose algae than other sites. On site III, the overall cover values were 34\%, 72\%, 69\% and $14 \%$ on the inner, middle, outer and fore reef, respectively. In contrast to site I, the upright fleshy canopy was the major contributor (up to $74 \%$ cover) at site III. Turf algae generally contributed least to the total cover and biomass (at most ca. 20\%) on reef flat zones. On the fore reef, crustose corallines and turf algae contributed most to the total at all sites, each group accounted for up to $50 \%$.

Egyptian J. of Phycol. Vol. 9, $2008 \quad$ - 62 - 

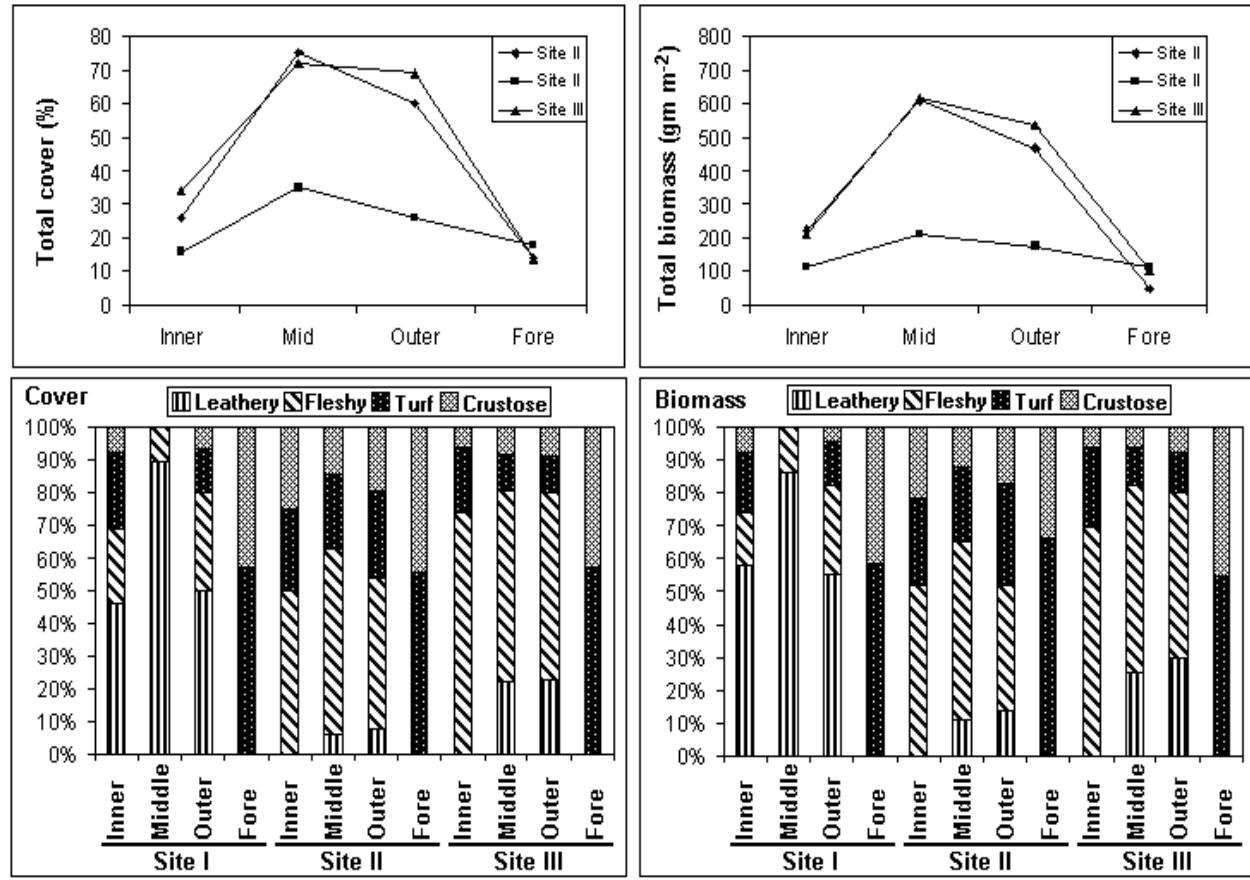

Figure 3: Contribution of different functional groups (below) to the overall cover and biomass of macroalgae on the reef zones of the investigated sites

\section{Discussion}

Algal communities at Ghardaqa reefs were highly variable in composition and abundance. Differences in seaweed composition were especially pronounced in northern and southern reefs. The northern reef (site I) had more abundant and conspicuous upright leathery macroalgal assemblage. In particular, the large brown Cystoseira frequently dominated the reef flat by dense and highly productive beds, up to $70 \mathrm{~cm}$ tall. Infrequently, other large brown seaweeds such as Sargassum, Turbinaria and Hormophysa intermixed in this bed with a variety of small green and red algae. In the area of the reef closest to the shore, there were generally some fleshy algae growing on sand and coral rubble. Upright leathery macroalgae greatly benefited from increases in substrate availability due to coral mortality at this reef. Large areas of dead corals covered by dark sediment with more turbid water and sheltering from strong wave action characterized the northern reef. Morrissey (1980) and McCook et al (2000) considered the dominance of Fucales as an indicator for reef degradation. Schaffelke and Klumpp (1997) and McCook et al. (1997) found a comparable dominance of such large brown algae on three nearshore fringing reefs in the central Great Barrier Reef, Australia and attributing it to reef sedimentation. 
Among the impacts of increased substrate availability due to coral mortality is a massive increase in the area and abundance of crustose corallines, turf algae and upright macroalgae (Hughes, 1994; Ostrander et al, 2000; McClanahan et al, 2001; Diaz-Pulido and McCook, 2002, 2004;Aronson and Precht, 2006). Turf algae are rapid colonizers of dead and injured corals (Done, 1992; Diaz-Pulido and McCook, 2002; Halford et al, 2004). Turf areas may undergo succession towards more upright macroalgae, because turf algae provide a more suitable substrate for macroalgae than live coral (Diaz-Pulido and McCook, 2002, 2004). The extent of this replacement will depend strongly on levels of herbivory and other factors such as nutrient availability. Increases in macroalgal colonization will increase coral-algal competition and inhibit coral recruitment and recovery, reducing overall reef resilience and stabilizing phase shifts from dominance by corals to dominance by turf and upright macroalgae (Jompa, 2001; Birrell et al, 2005). Ultimately, the response of each algal functional group to increased substrate availability will depend upon the overall characteristics of the given location. Szmant (2002) showed that high cover by crustose corallines and short, grazed turfs considered to be typical for healthy coral reefs, and the result of good water quality and high grazing rates. High cover by macroalgae, on the other hand, is often characteristic of degraded reefs, and ones with reduced grazers and/or poor water quality. The reef at site II, with low macroalgal coverage of upright, crustose and turf algae (all not exceed 30\%), could be an example of the healthy reef.

The southern reef (site III) could be considered as an intermediate stage of reef degradation. In contrast to northern reef, southern reef had low abundance of upright leathery canopy as well as low crustose and turf assemblages, but had high upright fleshy algae. Species of fleshy macroalgal genera such as the green algae Caulerpa, Dictyosphaeria and Halimeda, and the red algae Amphiroa, Digenea, Gelidium and Liagora were present. Brown algae were also present, with the most common genera including Padina, Dictyota, Turbinaria and Pocockiella, but generally in low abundance when compared with those found on Australian degraded reefs (McCook, 1996; McCook et al., 1997; Fabricius et al., 2005). Crustose corallines, including Porolithon, Neogoniolithon, Lithophyllum and Peyssonelia species were also low, but can contribute in some extent to reef formation (Ringeltaube and Harvey, 2000; Fabricius and De'ath, 2001). When comparing with the healthier reef at site II, there were much more abundant fleshy and turf algae as well as a greater number of different species on the southern reef. This is mostly due to effect in this part of the reef by fresh and wastewater runoff from tourist residences nearer the shore (Hanafi, unpublished data). This area of the reef has much more growth due to waves which carry nutrients to this area and take away sediments that could harm the corals.

Coral reef degradation is often evidenced by phase-shifts in community structure in which thick epilithic turfs and fleshy macroalgae overgrow reef 
substrate (Szmant, 2002). Potential causes for such shifts are multiple, and include factors that regulate rates of algal biomass production as well as ones that affect biomass consumption such as grazing. If anthropogenic nutrients are a major cause of increased algal abundance, then inshore reefs that are closer to such a source should have more algae than reefs further from shore. Effects of nutrient enhancement on the fecundity and productivity of macroalgae of the coral reefs have become apparent worldwide (e.g. Wolanski et al, 1988; Diaz-Pulido and McCook, 2005). The extensive clumps of Halimeda in the southern section of this site and in inter-reef shallow areas appear to be sustained by nutrients.

As a group, fleshy upright macroalgae are likely to benefit from many of the environmental changes brought about by tourism. Adapted species may find more space to colonize and may grow better when more optimal temperatures and nutrient are provided. However, future macroalgal communities are likely to change in composition as less adapted species are excluded and biological interactions change. Higher biomass and altered species composition of fleshy upright algae on coral reefs may change competitive interactions with corals and lead to impairment of coral recruitment, which would indirectly further reduce coral resilience (McCook et al, 2001).

In conclusion, coral reefs frequented by tourists may have to compete with destruction of critical habitat areas for development purposes, impacts associated with fishing pressure, and declines in water quality. The capacity of the ecosystem to adjust to these changes is limited and uncertain, and will depend on other aspects of resilience of the ecosystem. The functional groups of macroalgae (algal turfs, upright macroalgae, and crustose corallines) are useful as quick indicators for reef degradation due to stressors. In addition to the spatial variability of macroalgae, many species are highly seasonal in their occurrence, growth and reproduction and should be taken into consideration.

\section{References}

Abou-Aisha, K.M.; Shabana, E.F.; El-Abyad, M.S.; Kobbia, I.A. and Schanz, F. (1995). Seasonal changes in Cystoseira myrica and phosphorus input at two sites of the Red Sea Egyptian coasts. Water, air and soil pollution. 39: 199-211.

Aronson, R.B. and Precht, W. F. (2006). Conservation, precaution, and Caribbean reefs. Coral Reefs 25, 441-450 DOI 10.1007/s00338-006-01229.

Ateweberhan, M. Bruggemann, J. H. and Breeman, A. M. (2006). Effects of extreme seasonality on community structure and functional group dynamics of coral reef algae in the southern Red Sea (Eritrea). Coral Reefs. 25: 391406. 
Birrell, C. L.; McCook, L. J. and Willis, B. L. (2005). Effects of algal turfs and sediment on coral settlement. Marine Pollution Bulletin. 51: 40-414.

Chisholm, J. R. M. (2000). Calcification by crustose coralline algae on the northern Great Barrier Reef, Australia. Limnology and Oceanography. 45: 1476-1484.

Chisholm, J. R. M. (2003). Primary productivity of reef-building crustose coralline algae. Limnology and Oceanography. 48: 1376-1387.

Diaz-Pulido, G. and McCook, L. J. (2002). The fate of bleached corals: patterns and dynamics of algal recruitment. Marine Ecology Progress Series. 232: 115-128.

Diaz-Pulido, G. and McCook, L. J. (2004). Effects of live coral, epilithic algal communities and substrate type on algal recruitment. Coral Reefs. 23: 225233.

Diaz-Pulido, G. and McCook, L. J. (2005). Effects of nutrient enhancement of the fecundity of a coral reef macroalgae. Journal of Experimental Marine Biology and Ecology. 317: 13-24.

Done, T. J. (1992). Phase shifts in coral reef communities and their ecological significance. Hydrobiologia. 247: 121-132.

El-Manawy, I. M. and Gab-Alla, A. (2000). Distribution and biodiversity of seaweeds on coral reefs at Shalateen-Halaib sector (Red Sea, Egypt). The $1^{\text {st }}$ lent. Conf. Sci. Tanta Univ., 7: 73-87.

El-Manawy, I. M. and Shafik, M. A. (2000). Ecological and morphological studies on genus Caulerpa from the Egyptian Red Sea Coasts. Egypt. J. phycol., 1: 71-86.

Fabricius, K. E. and De'ath, G. (2001). Environmental factors associated with the spatial distribution of crustose coralline algae on the Great Barrier Reef. Coral Reefs.19, 303-309.

Fabricius, K. E.; De'ath, G.; McCook, L.; Turak, E. and Williams, D. M. (2005) Changes in algal, coral and fish assemblages along water quality gradients on the inshore Great Barrier Reef. Marine Pollution Bulletin, 51: 384-398.

Gattuso, J.P.; Frankignoule, M. and Wollast, R. (1998) Carbon and carbonate metabolism in coastal aquatic ecosystems. Annual Review of Ecology and Systematics, 29: 405-434.

Halford, A.; Cheal, A. J.; Ryan, D. and Williams, D.M. (2004). Resilience to large-scale disturbance in coral and fish assemblages on the Great Barrier Reef. Ecology, 85: 1892-1905. 
Harrington, L.; Fabricius, K. E.; De'ath, G. and Negri, A .P. (2004) Recognition and selection of settlement substrata determine post-settlement survival in corals. Ecology, 85: 3428-3437.

Hegazy, M. M. (1992). Ecological studies on the seaweeds of South Sinai. M.Sc. Thesis. Fac. Suez Canal Univ., pp.159.

Hughes, T. P. (1994) Catastrophes, phase-shifts and large-scale degradation of a Caribbean coral reef. Science. 265: 1547-1551.

Jompa, J. (2001) Interactions between macroalgae and scleractinian corals in the context of reef degradation. PhD Thesis, School of Marine Biology and Aquaculture, James Cook University, Townsville.

Klumpp, D.W. and McKinnon, A. D. (1992). Community structure, biomass and productivity of epilithic algal communities on the Great Barrier Reef: dynamics at different spatial scales. Mar Ecol-Prog Ser, 86:77-89.

Lipkin, Y. and Silva, P. C. (2002). Marine algae and seagrasses of the Dahlak Archipelago, southern Red Sea. Nova Hedwigia, 75:1-90.

Littler, M. M. and Littler, D. S. (1984) Models of tropical reef biogenesis: the contribution of algae. Progress in Phycological Research, 3: 323-364.

Littler, M. M.; Littler, D. S. and Taylor, P. R. (1983) Evolutionary strategies in a tropical barrier reef system: Functional-form groups of marine macroalgae. Journal of Phycology. 19: 229-237.

Marshall, J .F. and Davies, P. J. (1988) Halimeda bioherms of the northern Great Barrier Reef. Coral Reefs. 6: 139-148.

McClanahan, T.R.; Muthiga, N. A. and Mangi, S. (2001). Coral and algal changes after the 1998 coral bleaching: interaction with reef management and herbivores on Kenyan reefs. Coral Reefs, 19: 380-391.

McCook, L. J. (1996). Effects of herbivores and water quality on Sargassum distribution on the central Great Barrier Reef: cross-shelf transplants. Marine Ecology Progress Series, 139:179-192.

McCook, L. J. (1999). Macroalgae, nutrients and phase shifts on coral reefs: scientific issues and management consequences for the Great Barrier Reef. Coral Reefs, 18:357-367.

McCook, L. J.; De'ath, G.; Price, I. R.; Diaz-Pulido, G. and Jompa, J. (2000). Macroalgal resources of the Great Barrier Reef: taxonomy, distributions and abundances on coral reefs. Report to the Great Barrier Reef Marine Park Authority, Townsville.

McCook, L. J.; Jompa, J. and Diaz-Pulido, G. (2001) Competition between corals and algae on coral reefs: a review of evidence and mechanisms. Coral Reefs. 19: 400-417. 
McCook, L.J.; Price, I. R. and Klumpp, D. W. (1997). Macroalgae on the GBR: causes or consequences, indicators or models of reef degradation? Proceedings of the Eighth International Coral Reef Symposium, 2:18511856.

Morrissey, J. (1980). Community structure and zonation of macroalgae and hermatypic corals on a fringing reef flat of Magnetic Island (Queensland, Australia). Aquatic Botany. 8: 91-139.

Naser, A. H. (1947). Synopsis of the marine algae of the Egyptian Red sea coast. Bull. Fac. Sci-Egypt. Unvi, 26:1-155.

Nugues, M. M.; Smith, G. W.; Hooidonk, R. J.V.; Seabra, M. I. and Bak, R. P. M. (2004). Algal contact as a trigger for coral disease. Ecology Letters. 7: 919-923.

Ostrander, G. K.; Armstrong, K. M.; Knobbe, E.T.; Gerace, D. and Scully, E. P. (2000). Rapid transition in the structure of a coral reef community: the effects of coral bleaching and physical disturbance. Proceedings of the National Academy of Sciences. 97: 5297-5302.

Papenfuss, G. F. (1968). A history catalogue and bibliography of Red Sea benthic algae. Isr. J. Bot., 17: 1-119.

Rasser, M. and Piller, W. E. (1997). Depth distribution of calcareous encrusting associations in the northern Red Sea (Safaga, Egypt) and their geological implications. Proc. 8th Int. Coral Reef Sym., 1: 743-748.

Ringeltaube, P. and Harvey, A. (2000). Non-geniculate coralline algae (Corallinales, Rhodophyta) on Heron reef, Great Barrier Reef (Australia). Botanica Marina. 43:431-454.

Schaffelke, B. and Klumpp, D. W. (1997). Biomass and productivity of tropical macroalgae on three nearshore fringing reefs in the central Great Barrier Reef, Australia. Botanica Marina. 40: 373-383.

Sheppard, C. R. C. (2000). Coral reefs of the western Indian Ocean: an overview. In: McClanahan TR, Sheppard CRC, Obura DO (ed.) Coral reefs of the Indian Ocean-their ecology and conservation. Oxford University Press, New York, pp 3-38.

Smith, J.E.; Shaw, M. Edwards, R. A.; Obura, D.; Pantos, O.; Sala, E.; Sandin, S. A.; Smriga, S.; Hatay, M. and Rohwer, F. L. (2006). Indirect effects of algae on coral: algae-mediated, microbe induced coral mortality. Ecology Letters. 9:835-845.

Steneck, R. S. and Dethier, M. N. (1994). A functional group approach to the structure of algal-dominated communities. Oikos. 69: 476-498.

Szmant, A. M. (2002). Nutrient enrichment on coral reefs: Is it a major cause of coral reef decline? Estuaries. 25: 743-766.

Egyptian J. of Phycol. Vol. 9, $2008 \quad$ - 68 - 
Walker, D. I. (1987). Benthic algae. In: Edwards FJ, Head MS (ed.) Key environments: Red Sea. Pergamon, Oxford, UK. pp 152-168.

Wolanski, E.; Drew, E.; Abel, K. M. and O'Brien, J. (1988). Tidal jets, nutrient upwelling and their influence on the productivity of the alga Halimeda in the ribbon reefs, Great Barrier Reef. Estuarine, Coastal and Shelf Science. 26:169-201.

$$
\begin{aligned}
& \text { التباين المكانى لمجتمعات الطحالب البحرية ومجموعاتها الوظيفية على الشعاب }
\end{aligned}
$$

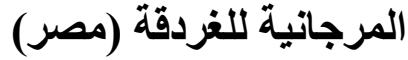

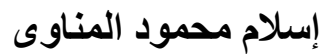

$$
\begin{aligned}
& \text { قسم النبات _ كلية العلوم - جامعة قناة السويب - الإسعاعبلية - مصر }
\end{aligned}
$$

تمت در اسة التباين المكانى للغطاء النباتى و الكتلة الحيوية للطحالب البحرية في ثلاثة مو اقع ممثلة

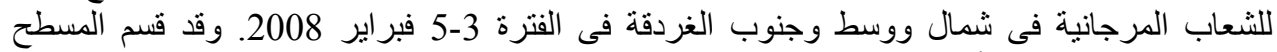



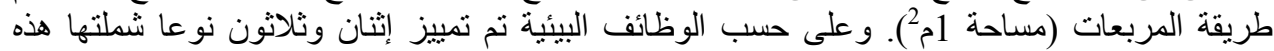

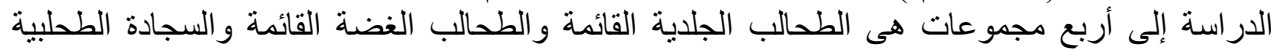

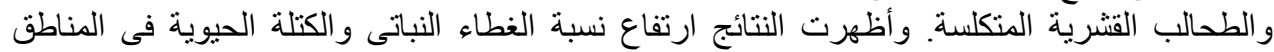

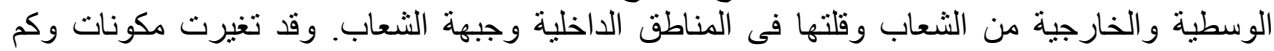

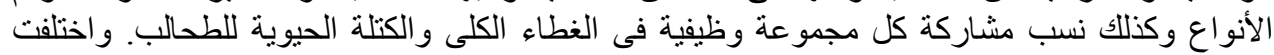

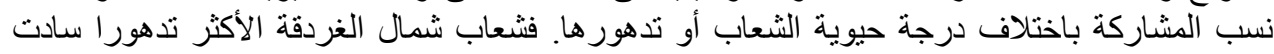

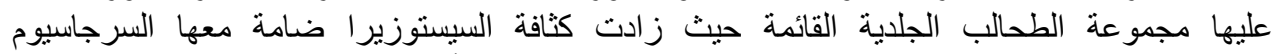

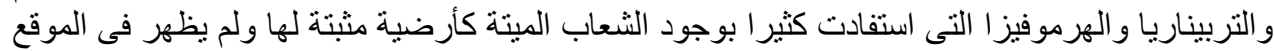

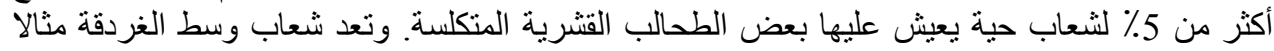

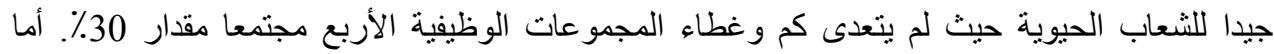

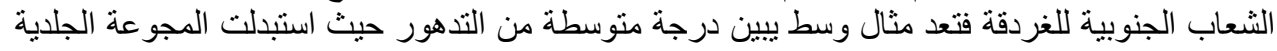

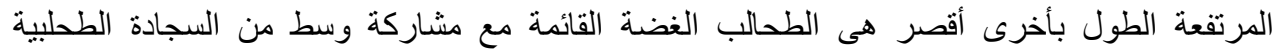

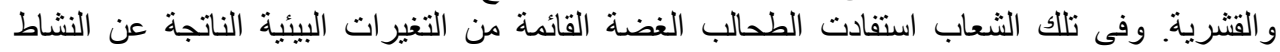



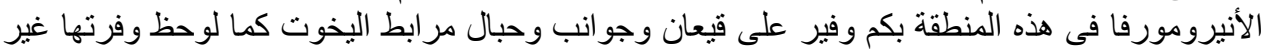



